\title{
Capital Structure Effect on the Practices of Earnings Management Phenomenon? The Evidence of Listed Firms in Abu Dhabi Securities Exchange
}

\author{
Dr. Mohammed Ibrahim Sultan Obeidat \\ Business Administration Department, Al Ain Campus \\ Al Khawarizmi International College \\ Al Ain-United Aram Emirates, P.O. Box: 68297 \\ E-mail: misobeidat_2015@yahoo.com/m.obeidat@khawarizmi.com
}

Received: Oct. 23, 2016 Accepted: Nov. 17, $2016 \quad$ Published: December 1, 2016

doi:10.5296/ajfa.v8i2.10198 URL: http://dx.doi.org/10.5296/ajfa.v8i2.10198

\begin{abstract}
The study objects for determining whether the listed firms in Abu Dhabi Securities Exchange exercise the phenomenon of earnings management in its financial reporting, and whether these practices are affected or driven by the capital structure of firms. To achieve the objectives of the study, a sample consisting of 29 listed firms at Abu Dhabi Securities Exchange (ADX) out of total 83 listed firms, had been selected using the simple random sampling method. Data covering 4-years was collected from the included firms in the sample, starting from 2012 till the end of 2015. The binomial distribution test is used to determine whether listed firms at ADX exercise the phenomenon of earnings management using the modified Jones 1995 model, whereas, the simple linear regression method is used to test whether the proportion of financial leverage in the capital structure of firms drives the practices of earnings management. The study shows that the firms exercise the phenomenon of earnings management, and the regression outputs show a significant positive effect of financial leverage on the practices of earnings management phenomenon.
\end{abstract}

Keywords: Earnings Management Phenomenon, Financial Leverage, Discretional Accruals, Debt Ratio, and Capital Structure 


\section{Introduction}

Earnings or what is called "net income", and "bottom line", is the most important item in the financial statements as a whole. Managers of business organizations may attempt to manage this item, mainly to affect the theoretical value of firms' stock, since the theoretical value of a firm's stock is actually the present value of its expected future cash flows (Lev, 1989). Other motives, in addition to firm value, may be available for managements to manage earnings. Some people misunderstand the term of earnings management when they believe that the practices of this phenomenon can't be considered ethical, and believe that it is normal ethical practice. In opposite to unethical accounting manipulation, earnings management is considered ethical, since it is a type of exploiting the flexibility level of accounting standards, where firms can select among alternative methods of measurement and recognition of revenues and expenses. Therefore, earnings management is seen by some interested people as a reasonable and an ethical management of decision making in intent to achieve a type of stable profits (Gaa, 2007).

Despite the viewpoint that exercising earnings management is legal, financial information should be relevant and reliable to enable investors, creditors, and other users of to make good and beneficial decisions. Managements have some incentives to exercise the phenomenon of earnings management, where this reduces the reliability of the reported earnings, so decisions taken by investors, creditors, and other users, may not be enough good. The phenomenon of earnings management, when exercised by managements leads to deceiving earnings to stockholders, investors, creditors, and other users, when they depend on this deceiving information. Management exploits the high level of flexibility that available in the accounting standards, where this flexibility enables management to use judgment in applying the revenue recognition principle. Therefore, more techniques and methods should be developed to detect the phenomenon of earnings management when it is exercised to influence the amount of the reported profits.

Next to several financial crises occurred during the last years of the last century and the first decade of the current century, the phenomenon of earnings management became under the focus of academics, authors, practitioners, and other interested people. Earnings management means revealing above or below the actual earnings through choosing the accounting methods that may lead to the desired result (Roychowdhury, 2006). Some financial indicators can be used to detect this phenomenon through using several available approaches and models, where some of these models are used to separate the nondiscretionary accruals from the total accruals. Non-discretional accruals do not involve earnings management practice, whereas discretionary accruals are rich field for practicing the phenomenon of earnings management.

The capital structure of business organizations consists of two sources, equity and debt. Using debt in the capital structure of firms differs from one country to another, from an industry to other, and also from firm to firm in the same industry and same country, depending on the needs of funding, and whether current stockholders have the desire and ability to provide the firm with its funding needs. The relationship between capital structure 
of firms and the practices of earnings management is still questionable, and no conclusive answer that debt affects or does not affect the practices of earnings management. Moreover, the consequences of earnings management may have strong negative effect on debt providers, in case the firm fails, and the fair value of its assets is less than the its total financial obligations.

The problem of the study may seem clear. Next to financial crises and firm's scandals during the last few years of the twentieth century, and the starting years of the current century, finding solutions to the phenomenon of earnings management and other manipulation practices became an urgent issue to protect investors, creditors, shareholders, and other groups of users from losses. Several procedures are taken to reduce the practices of earnings management such as the issuance of Sarbanes-Oxley Act, and corporate governance to reduce earnings management practices. Moreover, because the impact of financial leverage in terms of its proportion in this structure, is still questionable, the effect of financial leverage needs more and more investigations, since some studies found a positive effect of leverage on earnings management, others found no effect, whereas some found no relation. The problem of the study can be summarized in determining whether listed organization in Abu Dhabi Securities Exchange (ADX) exercise the phenomenon of earnings management, and to detect whether the financial leverage of these firms has an effect on these practices. The following two questions can better express the problem of the study. The first is; do listed firms at ADX exercise the phenomenon of earnings management? Whereas, the second is; do the financial leverage of listed firms in ADX affects the practices of earnings management by these firms? The study attempts to find clear cut answers for these two questions using the reported information by firms.

The study is important especially these days, where most firms attempt to reveal more profits than the actual. Managements have strong incentives to manage earnings, but the most important incentive is financial rewards, where more financial rewards will be received by managers when the reported profit is high, and in opposite, less or no financial rewards may be received by managers when less profit is reported. The importance of the study increases because no clear and conclusive answer to the effect of financial leverage on the practices of earnings management is available. The study also educates users and decision makers with the phenomenon of earnings management and offers methods or ways for its detection. In the United Arab Emirates (UAE), stock exchanges and the environment of earnings management had not been enough investigated, so this study is important to all developing stock exchanges and stockholders in developing countries, because it helps finding more protection to small investors and creditors against the harmful effects of earnings management phenomenon. The study is important also because it highlights the incentives for managers to manage earnings, so stronger and more incentives mean more probability to practice earnings management, and therefore these practices can be detected and users can be protected. More practices of earnings management lead to more fails among business organizations, and reducing the phenomenon practices means more investment growth in businesses and less fails.

The study objects for: 
1. Add more literature to the phenomenon of earnings management, including incentives, results, and the models that can be used to detect the practices of this phenomenon.

2. Measuring the practices of earnings management phenomenon by the listed firms at ADX, especially where this phenomenon is rarely studied in oil-based countries, where oil extraction forms a large proportion of its local production and income.

3. Determine whether the capital structure of listed firms in ADX affects the practices of earnings management phenomenon.

The remainder of the study proceeds as follows. Section 2 is dedicated for the literature and prior related researches. The hypotheses of the study are shown in section 3 , whereas section 4 presents the methodology used to accomplish the study. Results and analysis are shown in section 5, whereas section 6 shows the conclusions and findings of the study.

\section{Literature Review and Prior Researches}

Despite that the issue of earnings management is one among the hot topics since the collapse and corporate scandals in the last few years of the twentieth century, the term may still ambiguous for several groups of people. Earnings management is defined by Schipper (1998), as "a purposeful intervention in the external financial reporting process, with the intent of obtaining some private gain". The term of earnings management is also defined by Levitt (1998) as "a gray area where the accounting is being perverted, where managers are cutting corners and where earnings reports reflect the desire of management rather than the underlying financial performance of the Company". Other authors define earnings management as "a reasonable and legal management decision making and reporting intended to achieve stable and predictable financial results" "Rahman, Moniruzzaman, and Sharif, (2012).Healy and Wahlen (1998), provide a complete and clear definition of the term earnings management when they define it as "earnings management occurs when managers use judgment in financial reporting and in structuring transactions to alter financial reports to either mislead some stakeholders about the underlying economic performance of the company, or to influence contractual outcomes that depend on reported accounting numbers".

The discussion of the term of earnings management should include seven overlapping elements including, crime, suspects, weapons used, victims, motives, opportunity to carry out, and alternative explanations (Lo, 2007). Actually, when some one or more is exercising the phenomenon of earnings management, this means that a crime is committed. When there is a crime, there should be a perpetrator or more that made that crime. The murder, or the individual or group that are more common to carry out the crime of earnings management are normally the management or the managers because they have the motives to do that, whereas users of financial statements such as investors, creditors, and shareholders, are in most cases the victims. People normally do not commit without a motive or a reason. These reasons are called incentives which encourage people to commit a crime.

Sometimes, earnings management phenomenon is exercised by managers just to satisfy the prior expectations of earnings. In other situations, the management may manage earnings to receive high financial rewards because the amount of these rewards depends on the amount of 
reported earnings. Managers may manage earnings also to reduce the amount of income tax payables, or to influence the firm's share market price. Additional motives are available for managers to exercise the phenomenon of earnings management, but these are the most common incentives. The opportunity to manage earnings can be interpreted through the relationship between earnings management and earnings quality.

A link or a relationship between earnings management and earnings quality exists. Ball and Shivakumar (2007), stated that a negative relationship exists between earnings management and earnings quality, where quality of earnings quality declines as the level of earning management practices increases.

Several methods and techniques can be used to manage earnings. One common method is what is called acquisition accounting. Under the idea of acquisition accounting, GAAP had been amended in 2001, where the pooling of interests method became not allowed to be followed, and business firms should follow the purchase method as a unique method based on these amendments (Abu Ajeelah and Hamdan, (2009). The misuse of materiality is also another method that can be followed in exercising the phenomenon of earnings management. Materiality means the level of omission, misstatement, fraud, or change which may lead a decision maker to change his judgment may change and therefore the decision may change. The applications of revenue recognition principle are also an important instrument for managing earnings. Revenue is recognized when earned, realized, or realizable. The general rule is that revenue is recognized at point of sale for sales of tangible products, and when the service is rendered in full in case of services, because a probability appears that resource will inflow to the firm with amount can be measured reliably. In practice, firms may recognize revenue despite no enough ability exists that the resources will inflow to the fir, or may recognize revenue early or delaying this recognition intentionally to achieve an attractive purpose for the management. Cooking the books is also a known method in the practices of earnings management such as trade loading and channel staffing. More methods of managing earnings are available such as capitalizing expenses despite that it should be expensed within the current period. Nonrecurring expenses, pension plans, off balance sheet items, artificial rents, and cookie jar reserves, are all among the methods available to practice earnings management.

The decision of capital structure formation is one among the most important decisions in business organizations that taken by the firm's management or its board regarding the capital structure. The term capital structure refers to the proportion of each of equity and debt in funding the assets of the firm, so debt means the part that borrowed from creditors, whether it is cash as loans or purchasing and receiving services on credit. The term financial leverage refers to the amount of debt used in the capital structure of firms. More borrowing leads to more risks, but borrowing is preferable when the cost of borrowed funds is less than the rate that may be achieved when these borrowed funds are invested somewhere.

It is already known that more borrowing increases risk, but also borrowing may increase the profitability of the borrower when rate of interests on borrowing funds is sharply lower than the rate on these funds when used in investment. Actually this is called trade in equity, 
because this difference at end is due to shareholders, so rarely a firm borrows with a rate of interests exceeds the expected rate of return on investment. The weight of debt in the capital structure can be measured using different measures such as debt ratio and debt to equity ratio, but in this study the debt to equity ratio is used because it finds debt in proportional relation to total assets.

The issue of earnings management had been given enough interests and its importance is perceived carefully in the developed and western countries, but in the developing countries, including the Arab and other Middle East countries, the problem had not been given the deserved importance, especially that Arab Gulf countries do not impose income tax, so its economic system can be considered as different and unique system, where governmental revenues are not based on taxes. Actually, and based on the survey made to the literature of earnings management, no prior researches that investigating the issue of earnings management had been found, not only in UAE, but also in other Arab Gulf countries.

The most important and recent important study is that what carried out by Al Momani (2016), where the author investigated whether the traditional and modern performance indicators can explain the practices of earnings management phenomenon of the listed manufacturing firms at Amman Stock Exchange. The author used the modified (1995) Jones model in measuring the practices of earnings management for a data of a sample consisting of 29 firms covering the period 2006-2013. In details, three traditional indicators had been taken with consideration by the author including return on assets, return on sales, and cash flows from operations. Modern indicators tat the study takes into consideration are Tobin's-Q and the economic value added. The study shows that the manufacturing listed firms at Amman Stock Exchange are still exercising the phenomenon of earnings management, and a significant relationship exists between both of the traditional and modern indicators in one hand, and the practices of earnings management. The final conclusion of the study is that both of traditional and modern indicators have the ability to interpret the practices of earnings management.

Some of the prior researches that investigated the impact of financial leverage on the practices of earnings management phenomenon found that leverages increases earnings management practices, such as Kontorizos (2008), and Beatty and Weber (2003). In opposite, other prior researches found a negative impact of financial leverage on the phenomenon of earnings management and added that financial leverage restricts the management desire to manage earnings (Jelinek, 2007), (Wasimullah and others, 2010).

The characteristics of firms and their effect on earnings management were among the interests of Uwuigbe, Ranti, and Bernard, (2015). Their study is based on a sample consisting of 20 listed firms at the Nigerian Stock Exchange using the judgmental sampling method, and data covering the years 2006-2010 of these firms had collected and analyzed. In addition to the descriptive statistics and econometric analysis, the least square regression method had been used in data analysis and hypotheses testing. The study revealed an impact of each of firm size and corporate strategy on earnings management, but it did not find a significant effect of financial leverage on earnings management. 
Mozarpour and Norouzi (2015), investigated the effect of both capital structure and growth opportunities on earnings management using a sample of listed firms in Tehran Stock Exchange. The pooled data method had been used in data analysis and hypotheses testing. Results showed that there is a significant relationship between financial leverage and earnings management practices, whereas regarding the growth opportunities, the study revealed that there is a nonlinear and significant relationship between this variable and earnings management, and growth opportunities have a significant influence on this relationship.

The Impact of corporate governance on earning management practices was among the interests of Patrick, Paulinus, and Nympha, (2015). The authors actually investigated this relationship using a sample of Nigerian firms, where this sample had been selected using the purposive sampling technique between a period of 2011-2014. Simple linear regression had been used in data analysis and hypotheses testing. The study finds that the practices of corporate governance such as board size, board independency, firm size and the strength of audit committees, have a significant effect on earnings management practices.

Miloud (2014), studied the existence of earnings management in initial public offerings of French Firms. The author states that it is difficult to detect earnings management practices when the purpose of these practices is to increase the attractiveness of the offered stock. In case of exercising earnings management to make shares more attractive, these practices are done before the initial public offerings are made. In this study, the author examined earnings management through observing a time-series, where a sample consisting of French firms that went public between 1995 and 1998 on the Euronext Paris Exchange. The most important finding is that initial public offering firms with the highest discretionary current accruals are underperformed, compared with the equivalent firms in the third year following the initial public offering.

Uwuigbe, Peter, and Oyeniyi (2014) also investigated the effect of corporate governance mechanisms on earnings management in Nigeria. A sample of 40 listed firms in the Nigerian Stock Exchange had been used as a source of the primary required data using the judgmental sampling method. Regression analysis had been used in data analysis and in hypotheses testing. The findings of the study revealed that the board size and board independency had a negative significant influence on earnings management practices, whereas CEO duality had a positive significant impact. The study concludes that firms with larger boards and diverse knowledge have more ability to restrict the practices of earnings management, than smaller boards.

Kighir, Omar, and Mohamed (2014) made a revision to the different types of models used in detecting the practices of earnings management. The review found that robust models have been discovered in detecting earnings management, but these models are only available on the shelves of authors without utilization by industries. The authors recommended designing software of auditing or fraud detection from these models, especially discretionary accruals models, to be used by professionals and shareholders.

The relationship between board committees and earnings management was under the attention of Liu, Harris, and Omar (2013). The study investigates this relationship next to the 
international methods that made to strengthen corporate governance. A sample of 138 listed firms in Australian Stock Exchange had been selected to examine whether this relation exists. The main finding of the study is that the independency and activities of the board and sub-committees have a significant negative relationship with earnings management represented by the discretionary accruals.

Several researchers investigated the effect of firms' size on earnings management, among them is Cabej (2013), who studied this effect by using a sample of listed firms in Albania. Log of total assets is used to measure firms' size, while discretionary accruals used to measure the practices of earnings management using Jones model. Results showed that Albanian listed firms are engaged in earnings management initiatives but there are no significant differences among firms of different sized in their effect on the practices of earnings management phenomenon.

An, Li, and Yu, (2013, investigated the effect of earnings management practices on financial leverage, and the way this relationship is affected by institutional environments. The study employed using the data of 25,798 firms across 37 countries along the years 1889-2009. The study found that firms with high earnings management practices tend to have high corporate leverage, and this positive relationship is attenuated by strong institutional environments. Moreover, the results of the study lend strong support to the agency theory of free cash flows.

Zamri, Abdul Rahman, and Isa (2013), investigated the impact of financial leverage on real earnings management. The primary purpose of this study was to determine whether the financial leverage has an impact on the real earnings management. The abnormal cash flows from operations, the abnormal production costs, and the abnormal discretionary model by Roychowdhury, 2006, is used in this study as a proxy for real earnings management. The study is based on 3,745 firm-year observations along the period 2006-2011, listed in Bursa, Malaysia. The main finding of the study is that a significant negative correlation between financial leverage and the practices of earnings management and leveraged firms have lower level of earnings management.

Rani, Hussain, and Chand (2013), investigated the incentives standing behind managements' practices of earnings management. The authors developed a questionnaire directed toward a group of firms' key managers and members of board of directors of Fiji. The study demonstrated that the common incentives of earnings management of Fiji firms include management compensation, borrowing cost, meat/beat targets and expectations, and increase or decrease regulatory benefits or costs.

Gerakos (2012), stated that the current techniques used in identifying earnings management are sorely lacking, and they based on an assumption that accruals unexplained by discretionary accruals represent either earnings management practices or weak earnings quality, where these techniques suffer from measurement error and correlated omitted variables which lead to type I error and type II error. In addition, these techniques are estimated in the cross section where they do not take into consideration that earnings are better described by dynamic processes. 
A study that carried out by Rahman, Moniruzzaman, and Sharif (2012), investigated the techniques, motives, and controls of earnings management. In details, this study investigated some techniques that are used in managing earnings like cookie jar reserve, big bath, and big bet. Moreover, the study investigates some incentives for the practices of earnings management such as, market incentives, personal incentives, and political and regulatory motives. The study found that rigorous accounting standards, corporate governance and consciousness, awareness of the audit committee, and the morality of stakeholders, each of which plays a vital role in restricting the practices of earnings management and can control these practices (Lo, 2007).

Following the recent financial scandals and therefore the recent changes in the French institutional context, Benkraiem, (2012) investigated the role of corporate governance mechanisms in guaranteeing reliable and more accurate financial information that French firms issue. Empirical findings of the study showed that the present of independent directors can moderate the discretionary accruals management. The study adds that discretionary accruals management can also be restricted through the big 4 audit firms. Moreover, the study demonstrates that there is no significant relationship between ownership structure and the management of these accruals.

The impact of corporate governance on earnings management practices was the focus of Roodpohti and Chashmi (2011). The authors of the study hypothesized that corporate governance plays a role in reducing the harmful effects of earnings management practiced on shareholders and other users of financial information. The key objective of the study was to investigate the relationship between corporate governance internal and external mechanisms, and earnings management, where internal mechanisms of corporate governance includes ownership concentration, board independency, and CEO dominance, while external mechanisms include institutional shareholders according to the authors classification of corporate governance mechanisms. Required information was gathered based on a sample consisting of 196 firms of Tehran Stock Exchange between 2004 and 2008. Panel data method was used in the study to estimate its models. Findings of the study includes that firms with higher ownership concentration and board independence tend to manage earnings less than firms with higher institutional holdings. One additional finding of the study is that a positive relationship exists between CEO-Chairman duality and earnings management. Moreover, the study showed that firm size and leverage had been found that they have a positive relationship with earnings management phenomenon.

Tahir (2011), was among interested people with earnings management and its relation with the capital structure. The objective of the study was to identify the relating factors to earnings management and factors that having impact on capital structure. It is based on the published balance sheet by State Bank of Pakistan on non-financial listed firms at the Karachi Stock Exchange along 2001-2005. The study shows a negative coefficient, where the gearing ratio is negatively affected by return on assets. This negative relationship is justified that earnings management may have some effects on the capital structure of listed firms at Karachi Stock Exchange. 
Chen, Cheng, and Wang (2011), investigated whether increasing board independence leads to a reduction in earnings management practices. The study finds that non-compliance firms (firms that did not have a majority of independent directors prior to reforms), do not experience a significant reduction in earnings management practices from prior to afterwards of the reform. The study also shows that non-compliance firms that have low information acquisition cost experience a significant reduction in earnings management, when compared with other firms. The authors concluded that independent directors' control is more effective in environments of rich information.

Dechow, Hutton, and Kim (2011), provided a new approach for testing the accrual-based testing models of earnings management. In this new approach, the authors assumed that any accrual-based earnings management in one accounting period should be reversed in another accounting period, and incorporating the priors concerning the time of reversal will improve the power and specification of tests used to detect earnings management. The authors of the study found that incorporating the reversal increases the test power by more than $40 \%$, and provides a robust solution for reducing the model misspecification resulting from the correlated neglected variables.

An applied comparison is made between the modified Jones model (1995), and the Korean Model to determine which is the most effective one in detecting the practices of earnings management (Islam, Ali, and Ahmed, 2010). The authors mentioned that the modified Jones model is effective in detecting earnings management in the developed countries, but a model applied on the Korean Stock Exchange found more effective. Therefore, the authors of the study applied both of the modified Jones model and the Korean model on Bangladesh Capital Market, and found that the Korean model is more powerful than the modified Jones model in detecting the practices of earnings management.

Zhang and Liu (2009) carried out a study to investigate the impact of capital structure on earnings management and applied their study on Chinese listed firms from 2003 to 2007. The study demonstrates that the equity proportion of controlling shareholders has a U-shape relationship with earnings management practices, while a strong positive relationship of debt ratio on earnings management. In addition, the study shows that the equity proportion of executives and external majority shareholders' share impact on earnings management is weak.

Earnings management through real activities manipulation had been investigated carefully by Roychowdhury (2006). The author took into consideration the relationship between some factors and earnings management. The study found evidence that managers manipulate real activities of firms to avoid losses reporting. In more details, the study showed evidence for making price discounts to increase sales, overproduction to reduce cost of goods sold, and reduction of discretionary expenditures to increase reported margins. Moreover, the study reveals that industry membership, the stock of inventories and receivables, and incentives to meet zero profits, are all affect the manipulation of real activities.

Kim and Liu (2003), also carried out a study to investigate the effect of firms' size on earning management. The authors of the study classified firms into small, medium, and large sized 
firms. The study finds that both large and small sized-firms manage earnings to avoid the announcement of small negative earnings or small reduction in earnings. The study concludes that small firms exercise more earnings management than large and medium sized-firms to avoid the reporting of small losses, whereas medium and large-sized firms manage earnings to avoid reporting earnings decreases than small-sized firms.

One study by Peasnell, Pope, and Young (1999) used a developed model called margin model, in addition to (Jones 1991) and (Dechow 1995) models. The study found that each of the above three mentioned models is well specified when applied to a random sample of firm-years, but the margin model generates relatively better specified estimates of abnormal accruals when cash flow is extreme. The analysis of the above three mentioned models, revealed that the ability to detect earnings management are capable to generate powerful tests for economically plausible levels of accruals management. The study demonstrated that the standard-Jones and Modified-Jones are more powerful for revenue and bad-debt manipulation, but the margin model is more powerful in detecting non-bad debt expense manipulation. Therefore, the study concludes that different models are required in different circumstances.

Dechow, Sloan, and Sweeney (1995), investigated the alternative accrual-based models for detecting the practices of earnings management. They used several measures of discretionary accrual models. The authors applied all available models to a random sample of US firms. Their study highlighted the importance of controlling financial performance in investigating whether earnings management phenomenon is used. Among the available models, the study found that the modified Jones Model has the strongest power in investigating earnings management phenomenon.

Based on the review made to the related literature of earnings management phenomenon, and the prior related researches, it is apparent, that some prior researches found no relationship between the capital structure and the phenomenon of earnings management (Mozarpour and Norouzi, 2015) (An, Li, and Yu, 2013) (Zamri, Abdul Rahman, and Isa, 2013) (Roodpohti and Chashmi, 2011), whereas other showed that this relation exists (Uwuigbe, Ranti, and Bernard, 2015) (Benkraiem, 2012) (Tahir, 2011) (Zhang and Liu, 2009), despite that among which, some declared that this relation is positive, while others declared that it is negative. These different findings must be considered incentives for authors and academics for more investigations of the phenomenon of earnings management in different countries, especially the developing countries. Table (1) summarizes the findings of some related prior researches regarding the relationship between the capital structure and the phenomenon of earnings management. 
Table 1. Summary of prior researches conclusions

\begin{tabular}{|l|l|l|l|}
\hline Author & Year & $\begin{array}{l}\text { Significant } \\
\text { Relationship }\end{array}$ & $\begin{array}{l}\text { No } \text { Significant } \\
\text { Relationship }\end{array}$ \\
\hline $\begin{array}{l}\text { Uwuigbe, Ranti, and } \\
\text { Bernard }\end{array}$ & 2015 & $\checkmark$ & \\
\hline Mozarpour and Norouzi & 2015 & $\checkmark$ & \\
\hline An, Li, and Yu & 2013 & $\checkmark$ & $\checkmark$ \\
\hline $\begin{array}{l}\text { Zamri, aBdul Rahman, and } \\
\text { ISA }\end{array}$ & 2013 & & $\checkmark$ \\
\hline Benkraiem, (2012) & 2012 & & \\
\hline $\begin{array}{l}\text { Tahir } \\
\text { Roodpohti and Chashmi }\end{array}$ & 2011 & $\checkmark$ & $\checkmark$ \\
\hline Zhang and Liu & 2011 & & \\
\hline
\end{tabular}

The table summarizes the conclusions of the most related prior researches, where it includes only the findings of those prior researches that investigated the relationship between debt and earnings management phenomenon

\section{Research Hypotheses}

Based on the revision that made to the literature of earnings management, and the consideration of prior related researches, five hypotheses were developed to achieve the objectives of the study. All hypotheses had been stated in their null form. These hypotheses are as follows:

$\mathrm{HO}_{1}$ : Listed firms in Abu Dhabi Securities Exchange do not exercise the phenomenon of earnings management.

Ho2: Capital structure of listed Construction equipment firms in Abu Securities Exchange does not affect the practices of earnings management in these firms.

\section{Research Methodology}

The structure of the study consists of one dependent variable and one independent variable. The dependent variable is earnings management, while the capital structure is the independent variable. A sample consisting of 29 firms had been selected from the total 82 listed firms in ADX, using simple random sampling method. :

Based on the concept of earnings management, which occurs when managers use their judgment in financial reporting and in structuring transactions to alter the financial reports to mislead stakeholders regarding the economic performance of a firm or to affect the contractual outcomes that normally depend on the amounts of reported items in the financial statements (Healy and Whalen, 1998), the modified Jones model is used for separating discretionary accruals from total accruals, and discretionary accruals is used as a measure for the practices of earnings management phenomenon. Different authors found that the modified Jones (1995) model that adjusted by Dechow, Sloan, and Sweeney, (1995), is the most 
powerful among the available models to detect earnings management, (Dechow, Sloan, and Sweeney, 1995)(Islam, Ali, and Ahmed, 2010), (Peasnell, Pope, and Young, 1999), (Momani, 2016).The modified (1995) Jones model uses the discretionary accruals as an indicator of earnings management practice, where a higher absolute value of discretionary accruals means less earning quality. Two approaches are available to determine total accruals, the income statement approach, and the balance sheet approach. For the purposes of the current study, the income statement approach is used, where based on this approach total accruals are computed by subtracting the net cash flows from operating activities from the operating income in the income statement. Thefollowing equation is used to determine the amount of net income from the financial statement.

$$
\mathrm{TA}_{\mathrm{t}}=\mathrm{OI}_{\mathrm{t}}-\mathrm{CFFOA}_{\mathrm{t}}
$$

Where:

$\mathrm{TA}_{t}$ : Total Accruals in period $\mathrm{t}$

OIt: Income of year $t$

$\mathrm{CFFOA}_{\mathrm{t}}$ : Cash flows from operating activities in year $\mathrm{t}$.

To compute the nondiscretional accruals for firm $\mathrm{j}$ in year $\mathrm{t}$, the parameters of the cross-sectional modified Jones (1991) model are estimated using the following equation.

$\mathrm{TA}_{\mathrm{j}, t} / \mathrm{A}_{\mathrm{j}, \mathrm{t}-1}=\alpha+\beta 1\left(1 / \mathrm{A}_{\mathrm{j}-\mathrm{t}-1}\right)+\beta 2\left[\left(\Delta R E V_{j, t}-\Delta R E C_{j, t}\right) / A_{j, t-1}\right]+\beta 3\left(\mathrm{PPE}_{\mathrm{j}, t} / \mathrm{A}_{\mathrm{j}, \mathrm{t}-1}\right)+\mathrm{E}_{\mathrm{j}, \mathrm{t}}$.

Where:

$\mathrm{TA}_{\mathrm{j}, \mathrm{t}}=$ Total accruals of firm $\mathrm{j}$ for year $\mathrm{t}$.

$\Delta \mathrm{REV}_{\mathrm{j}, \mathrm{t}}=$ Change in revenue of firm $\mathrm{J}$ between year $\mathrm{t}$ and year $\mathrm{t}-1$.

$\triangle \mathrm{RECE}_{\mathrm{j}, \mathrm{t}}$ : Change in receivables of firm $\mathrm{j}$ between year $\mathrm{t}$ and year $\mathrm{t}-1$.

$\mathrm{PPE}_{\mathrm{j}, \mathrm{t}}$ : Gross property, plant, and equipment of firm $\mathrm{j}$ industry $\mathrm{j}$ for year $\mathrm{t}$.

$A_{j, t-1}:$ Total assets of firm $j$ by the end of year $t-1$.

Et: Residuals, where it represents that part of total accruals that cannot be interpreted by the variables of regression, and used as a proxy representing discretionary accruals.

Applying the above regression equation, 29 equations became available for each year of 2012, 2013 , 2014, and 2015. Using the parameters $(\beta 1, \beta 2$, and $\beta 3)$ the nondiscretional accruals had been estimated using the following equation:

$$
\mathrm{TA}_{\mathrm{j}, t} / \mathrm{A}_{\mathrm{j}, \mathrm{t}-1}=\hat{\mathrm{a}}+\beta 1\left(1 / \mathrm{A}_{\mathrm{j} \mathrm{j}-1}\right)+\beta 2\left[\left(\Delta R E V_{j, t}-\Delta R E C_{j, t}\right) / A_{j, t-1}\right]+\beta 3\left(\mathrm{PPE}_{\mathrm{j}, t} / \mathrm{A}_{\mathrm{j}, \mathrm{t}-1}\right)+\mathrm{E}_{\mathrm{j}, \mathrm{t}}
$$

Then the discretional accruals had been computed using the following relation:

$$
|\mathrm{DACi}, \mathrm{t} / \mathrm{Ai}, \mathrm{t}-1|=|\mathrm{TAC} \mathrm{i}, \mathrm{t} / \mathrm{Ait}-1-\mathrm{NDACi}, \mathrm{t} / \mathrm{Ai}, \mathrm{t}-1|
$$


Where

$\mathrm{DAC}_{\mathrm{j}, \mathrm{t}} / \mathrm{A}_{\mathrm{i}, \mathrm{t}-1}$ refers to discretional accruals to prior assets of firm $\mathrm{j}$ in year $\mathrm{t}$.

Next to the computations of discretionary accruals of each firm for 4 years, the absolute value of discretional accruals and the average of this value were computed for each firm along the period of the study. To determine whether each included firm in the sample exercised earnings management, the absolute value of accruals is compared with average of these accruals, so when the absolute value of the firm's accruals is above the average, this means that the firm exercised the phenomenon of earnings management, and given number 1 as a factious, while it is given 0 , when the absolute value of accruals is less than the average of its discretional accruals.

The single independent variable of the study is capital structure. Debt ratio is used to measure the capital structure of firms, where debt ratio is the relation of total debts to total assets. Therefore, the following regression method is used as the model of the study.

$$
\mathrm{EM}=\mathrm{a}+\mathrm{bDt}+\mathrm{E}
$$

EM: refers to the phenomenon of earnings management

Dt: refers to Debt ratio

a: Constant represent the value of earnings management when debt ratio equals zero.

b. represents the slope of debt ratio on discretionary accruals or the phenomenon of earnings management.

E: the standard error of the model.

The binomial distribution method is used to analyze the first hypotheses which hypothesized that the listed firms in ADX exercise the phenomenon of earnings management, whereas the simple linear regression method is used to test the second hypothesis regarding whether the capital structure of listed firms in ADX affects the practice of earnings management phenomenon. A 95 percent level of confidence $(\mathrm{Sig}=0.05$ ) is used for the decision rule of accepting or rejecting the null hypotheses.

\section{Results and Analysis}

\subsection{The First Hypothesis}

Applying the steps of finding the discretional accruals, table (2) shows the average as a good central tendency measure, the standard deviation as a good measure of variation, the minimum value, and the maximum value of the proportional discretionary accruals to total assets of prior year. Based on information appearing in table (2), the highest mean of the discretionary accruals to total prior assets is due to year 2013, whereas the lowest one is attributed to year 2015. The standard deviation for the year of the highest mean is 0.05734 , whereas its value for the year of the lowest mean is 0.033 . Mean of the total period of the study is -0.0288 at a standard deviation of 0.0228 . 
Table 2. Discretionary Accruals to Total Prior Assets

\begin{tabular}{|l|l|l|l|l|}
\hline & \multicolumn{4}{|c|}{ Discretionary Accruals to Total Prior Assets } \\
\hline Year & Mean & Standard Deviation & Maximum & Minimum \\
\hline 2012 & -.01999 & 0.01922 & 0.01869 & -0.01922 \\
\hline 2013 & -0.05827 & 0.05734 & 0.03454 & -0.28340 \\
\hline 2014 & -0.02222 & 0.017522 & -0.00010 & -0.06141 \\
\hline 2015 & -0.01553 & 0.03309 & 0.05023 & -0.10245 \\
\hline Along the Period of the Study & -0.02880 & 0.02280 & 0.01186 & -0.11976 \\
\hline
\end{tabular}

The table shows the descriptive statistics for the discretionary accruals in proportion to total prior assets

The average for each firm had been computed, and when the firm has accruals in one year above the average it is classified as a practitioner to the phenomenon of earnings management in that year and therefore given the number one, whereas if it's accruals below the mean, it is considered not practitioner to the phenomenon, and therefore given the number zero for the purpose of using the binomial distribution test. The results of this process are shown in table (3). Based on information appears in table (3), the least number of firms that practiced earnings management was on 2012, where only 5 firms, or 17 percent of the total firms included in the sample exercised the phenomenon. In opposite the highest number of firms that exercised the phenomenon is recorded on year 2014, where 19 firms, or 66 percent of the firms included in the sample exercised earnings management. In total, 47 observations of practicing earnings management, while 69 negative observation of non-practicing earnings management.

Table 3. Practicing firms of Earnings Management Phenomenon

\begin{tabular}{|l|l|l|l|l|l|l|}
\hline \multirow{2}{*}{ Year } & \multicolumn{2}{|l|}{ Exercising Firms } & \multicolumn{2}{|l|}{ Non-Exercising Firms } & $\begin{array}{c}\text { Total } \\
\text { Proportion }\end{array}$ & $\begin{array}{c}\text { Total } \\
\text { Frequency }\end{array}$ \\
\cline { 2 - 5 } & Frequency & Proportion & Frequency & Proportion & $100 \%$ & 29 \\
\hline 2012 & 5 & 0.17 & 24 & 0,83 & $10 \%$ & 29 \\
\hline 2013 & 9 & 0.31 & 20 & 0.69 & $100 \%$ & 29 \\
\hline 2014 & 19 & 0.66 & 10 & 0.34 & $100 \%$ & 29 \\
\hline 2015 & 14 & 0.48 & 15 & 0.52 & $100 \%$ & 116 \\
\hline Total & 47 & $41 \%$ & 69 & $59 \%$ & $100 \%$ & \multicolumn{2}{|l}{} \\
\hline
\end{tabular}

The table shows both of frequency and proportion of practicing and non-practicing firms to the phenomenon of earnings management

\subsubsection{Testing the First Hypothesis}

The first hypothesis of the study assumes that the listed firms in ADX do not practice the phenomenon of earnings management. The hypothesis is represented again as follows: 
$\mathrm{HO}_{1}$ : Listed firms in Abu Dhabi Securities Exchange do not exercise the phenomenon of earnings management.

The binomial distribution test had been used to test the first hypothesis, since a firm practices or does not practice the phenomenon and no third possible option is available. The hypothesis is tested at 95 percent level of confidence. The analysis shows that 47 out of 116 observations were positive or exercising, which represents 41 percent out of 116 total observations, whereas 69 observations are negative observations or not exercising, or 59 percent of the total number of observations. The p-value (exact-sig) is exactly 0.05. Because the computed p-value exceeds the tabulated one, the null hypotheses is rejected, while instead the alternative one is accepted, which states that listed firms in ADX practice the phenomenon of earnings management. In other words, the test of the hypothesis approves the practice of earnings management phenomenon by some listed firms in ADX. Table (4) shows the binomial distribution results of analysis.

Table 4. Binomial Statistics

\begin{tabular}{|l|l|l|l|l|l|}
\hline Hypothesis & $\begin{array}{l}\text { No. of Firms } \\
\text { Exercising Ear. } \\
\text { Management }\end{array}$ & Proportion & $\begin{array}{l}\text { No. of Firms not } \\
\text { Exercising Ear. } \\
\text { Management }\end{array}$ & Proportion & $\begin{array}{l}\text { P-Value } \\
\text { (sig) }\end{array}$ \\
\hline $\mathrm{HO}_{1}$ & 47 & $41 \%$ & 69 & $59 \%$ & 0.05 \\
\hline
\end{tabular}

The table shows the related statistics to hypothesis (1), using binomial distribution

\subsection{The Second Hypothesis}

The second hypothesis is developed to examine whether the capital structure of firms affect the practices of earnings management phenomenon. As mentioned above, the debt ratio is used as indicator for the capital structure. Debt ratio is computed by dividing total liabilities by total assets. Table (5) shows the mean, standard deviation, minimum debt ratio, and the maximum one for each year and in total for all years together. Based on the table, the mean of debt ratio of all years is between 0.4 and 0.5 , which is considered normal, despite that some high and low debt ratios for some firms in few years. The highest mean of debt ratio is recorded on year 2013, where it is 0.47775 , whereas the lowest is 0.41576 , and attributed to year 2012. The standard deviation for the year of the highest mean is 0.276 , whereas the one for the year of the lowest mean is 0.306 .

Table 5. Debt Ratio Statistics

\begin{tabular}{|l|l|l|l|l|}
\hline Year & Mean & Minimum & Maximum & Standard Deviation \\
\hline 2012 & 0.41576 & 0.001 & 0.896 & 0.306 \\
\hline 2013 & 0.47775 & 0.056 & 0.899 & 0.276 \\
\hline 2014 & 0.47587 & 0.047 & 0.924 & 0.283 \\
\hline 2015 & 0.46520 & 0.064 & 0.933 & 0.286 \\
\hline Total & 0.45864 & 0.001 & 0.933 & 0.285 \\
\hline
\end{tabular}

The table presents the descriptive statistics of debt ratio 


\subsubsection{Testing the Second Hypothesis}

The second hypothesis is developed to represent the assumed effect of capital structure of firms on the practices of earnings management phenomenon. The second hypothesis is presented again as follows:

Ho2: Capital structure of listed Construction equipment firms in Abu Securities Exchange does not affect the practices of earnings management in these firms.

Table (6) shows total assets, total liabilities, and the debt ratio for each firm within the sample in each year along the period of the study. The table shows that the debt ratio sharply differs from one firm to another and slightly from year to year for the same firm. The large differences are attributed to the difference in industry each firm in the sample belongs for. Some firms belong to building equipment, others for commercial banking industry, and others for food or and services. The highest debt ratio is 93.3 percent, and recorded in year 2015, whereas the least on is 0.001 , and recorded on 2002.

Table 6. Debt Ratio

\begin{tabular}{|c|c|c|c|c|}
\hline Ser. No & Year & Liabilities & Total Assets & Debt Ratio \\
\hline \multirow[t]{4}{*}{ Firm 1} & 2012 & 408,246 & $3,585,558$ & 0.114. \\
\hline & 2013 & 338,139 & $3,309,349$ & 0.102 \\
\hline & 2014 & $1,892,244$ & $4,304,946$ & 0.440 \\
\hline & 2015 & $2,055,211$ & $4,670,458$ & 0.440 \\
\hline \multirow[t]{4}{*}{ Firm 2} & 2012 & $1,812,111$ & 301,000 & 0.001 \\
\hline & 2013 & $1,401,907$ & $1,847,401$ & 0.759 \\
\hline & 2014 & $1,356,480$ & $1,738,787$ & 0.780 \\
\hline & 2015 & 987,538 & $1,365,781$ & 0.723 \\
\hline \multirow[t]{4}{*}{ Firm 3} & 2012 & 754,787 & $1,128,931$ & 0.669 \\
\hline & 2013 & 713,786 & $1,249,832$ & 0.571 \\
\hline & 2014 & 829,570 & $1,379,713$ & 0.601 \\
\hline & 2015 & 830,633 & $1,544,411$ & 0.538 \\
\hline \multirow[t]{4}{*}{ Firm 4} & 2012 & $1,584,301$ & $3,240,494$ & 0.489 \\
\hline & 2013 & $1,802,194$ & $3,505,489$ & 0.514 \\
\hline & 2014 & $1,907,507$ & $3,697,540$ & 0.516 \\
\hline & 2015 & $1,846,258$ & $3,693,626$ & 0.500 \\
\hline \multirow[t]{4}{*}{ Firm 5} & 2012 & 612,552 & $1,454,565$ & 0.421 \\
\hline & 2013 & 627,538 & $1,236,810$ & 0.507 \\
\hline & 2014 & 107,283 & 559,194 & 0.192 \\
\hline & 2015 & 99,028 & 605,995 & 0.163 \\
\hline \multirow[t]{4}{*}{ Firm 6} & 2012 & $473,576,6$ & $792,563.421$ & 0.006 \\
\hline & 2013 & $452,066.8$ & $884,329.690$ & 0.511 \\
\hline & 2014 & $439,815.4$ & $842,417.115$ & 0.522 \\
\hline & 2015 & $340,870.3$ & $585,947.931$ & 0.582 \\
\hline Firm 7 & 2012 & $10,734,886$ & $12,739,343$ & 0.843 \\
\hline
\end{tabular}




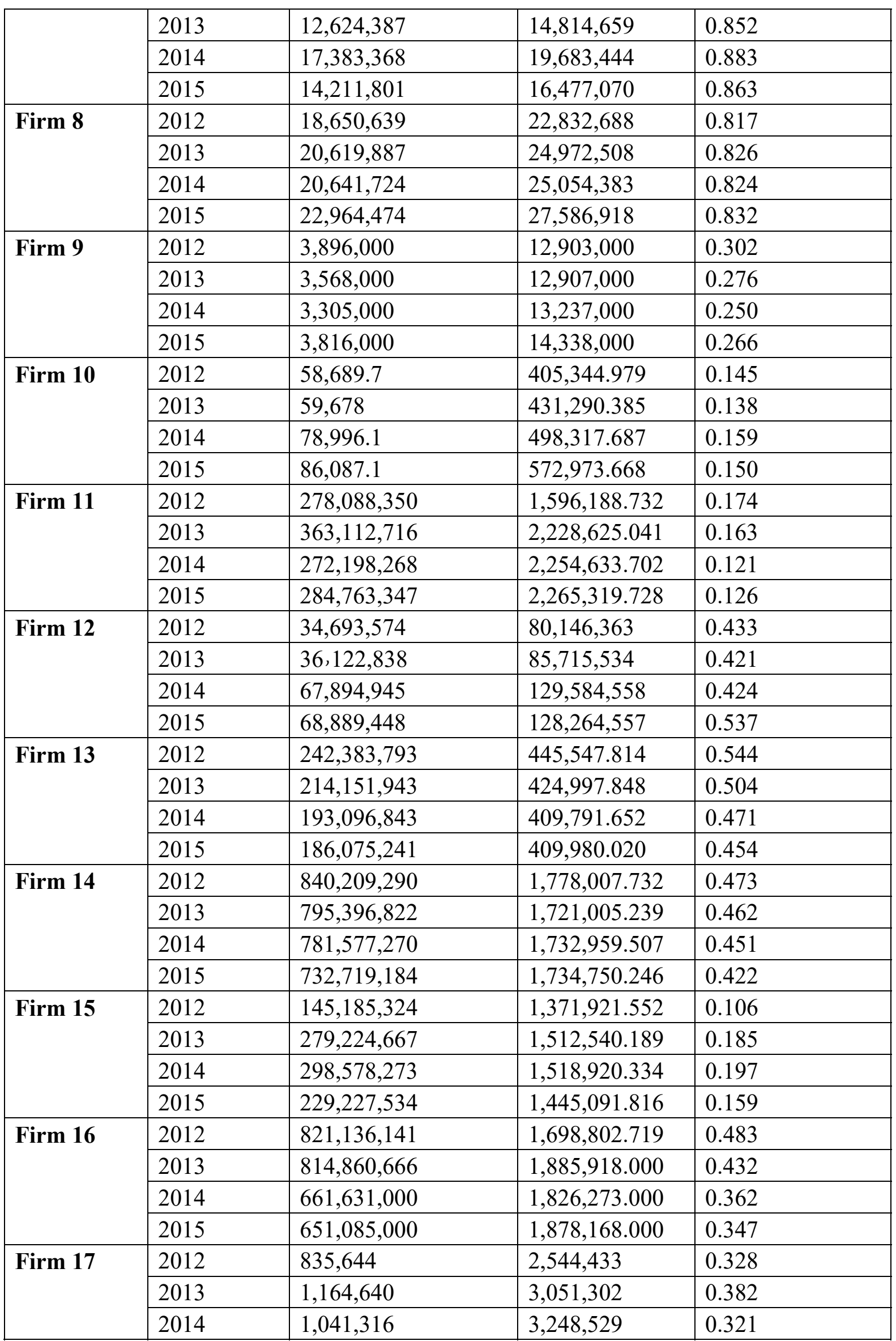




\begin{tabular}{|c|c|c|c|c|}
\hline & 2015 & $1,163,045$ & $3,455,834$ & 0.337 \\
\hline \multirow[t]{4}{*}{ Firm 18} & 2012 & $52,385,535$ & $283,826,793$ & 0.185 \\
\hline & 2013 & $50,345,046$ & $333,701,647$ & 0.151 \\
\hline & 2014 & $55,754,252$ & $365,920,988$ & 0.152 \\
\hline & 2015 & $65,052,839$ & $378,367,249$ & 0.172 \\
\hline \multirow[t]{4}{*}{ Firm 19} & 2012 & $269,466,078$ & $300,599,169$ & .0 .896 \\
\hline & 2013 & $290,383,115$ & $325,061,656$ & 0.893 \\
\hline & 2014 & $338,135,330$ & $376,098,712$ & 0.899 \\
\hline & 2015 & $363,345,154$ & $406,563,807$ & 0.894 \\
\hline \multirow[t]{4}{*}{ Firm 20} & 2012 & $1,801,558$ & $3,486,496$ & 0.517 \\
\hline & 2013 & $1,758,945$ & $3,340,409$ & 0.527 \\
\hline & 2014 & $1,617,237$ & $3,354,870$ & 0.482 \\
\hline & 2015 & $1,188,446$ & $4,615,329$ & 0.257 \\
\hline \multirow[t]{4}{*}{ Firm 21} & 2012 & $49,693,834$ & $723,040.547$ & 0.069 \\
\hline & 2013 & $41,346,210$ & $736,586.793$ & 0.056 \\
\hline & 2014 & $33,439,336$ & $710,784.059$ & 0.047 \\
\hline & 2015 & $43,150,443$ & $674,858.591$ & 0.064 \\
\hline \multirow[t]{4}{*}{ Firm 22} & 2012 & $30,054,032$ & $5,311,992$ & 0.006 \\
\hline & 2013 & $3,039,861$ & $5,679,296$ & 0.535 \\
\hline & 2014 & $2,965,062$ & $5,999,875$ & 0.494 \\
\hline & 2015 & $3,044,323$ & $5,981,775$ & 0.509 \\
\hline \multirow[t]{4}{*}{ Firm 23} & 2012 & $73,431,869$ & $85,664,555$ & 0.857 \\
\hline & 2013 & $90,086,594$ & $103,160,486$ & 0.873 \\
\hline & 2014 & $98,217,136$ & $111,903,803$ & 0.878 \\
\hline & 2015 & $103,302,431$ & $118,377,662$ & 0.873 \\
\hline \multirow[t]{4}{*}{ Firm 24} & 2012 & $243,920,739$ & $977,439.645$ & 0.250 \\
\hline & 2013 & $359,933,672$ & $1,244,536.911$ & 0.289 \\
\hline & 2014 & $362,343,555$ & $1,256,066.884$ & 0.288 \\
\hline & 2015 & $294,017,652$ & $1,141,042.624$ & 0.258 \\
\hline \multirow[t]{4}{*}{ Firm 25} & 2012 & 442,695 & $1,755,287$ & 0,522 \\
\hline & 2013 & 454,874 & $1,883,814$ & 0.241 \\
\hline & 2014 & 449,023 & $1,889,157$ & 0.238 \\
\hline & 2015 & 458,952 & $1,851,124$ & 0.248 \\
\hline \multirow[t]{4}{*}{ Firm 26} & 2012 & $13,872,331$ & $17,733,142$ & 0.782 \\
\hline & 2013 & $17,195,994$ & $21,731,901$ & 0.791 \\
\hline & 2014 & $21,424,496$ & $26,012,888$ & 0.824 \\
\hline & 2015 & $25,178,292$ & $28,882,693$ & 0.872 \\
\hline \multirow[t]{4}{*}{ Firm 27} & 2012 & 109,277 & $122,590,000$ & 0.891 \\
\hline & 2013 & 109611 & $121,925,000$ & 0.899 \\
\hline & 2014 & 106,254 & $115,038,000$ & 0.924 \\
\hline & 2015 & 101,436 & $108,767,000$ & 0.933 \\
\hline Firm 28 & 2012 & $13,367,992$ & $15,012,589$ & 0.890 \\
\hline
\end{tabular}




\begin{tabular}{|l|l|l|l|l|}
\hline & 2013 & $19,068,225$ & $21,549,756$ & 0.885 \\
\cline { 2 - 5 } & 2014 & $22,797,624$ & $25,709,285$ & 0.887 \\
\cline { 2 - 5 } & 2015 & $21,093,668$ & $23,681,623$ & 0.891 \\
\hline \multirow{4}{*}{ Firm 29 } & 2012 & 162,271 & $1,418,071$ & 0.114 \\
\cline { 2 - 5 } & 2013 & 150,887 & $1,407,870$ & 0.107 \\
\cline { 2 - 5 } & 2014 & 104,892 & $1,391,264$ & 0.075 \\
\cline { 2 - 5 } & 2015 & 114,138 & $1,368,832$ & 0.083 \\
\hline
\end{tabular}

The table provides the liabilities, total assets, debt ratio and amount of discretionary accruals for each firm in the sample in each year.

The simple linear regression method had been used in testing the second hypothesis since it is appropriate to examine whether a single independent variable affects another dependent variable. The dependent variable in this study is the practices of earnings management phenomenon, whereas the independent one is the capital structure of firms. While the practices of earnings management phenomenon are measured through the discretional accruals of firms along the period of the study, the capital structure is measured through the debt ration of each firm in each year along the period of the study.

Table (7) shows the results of simple linear regression using the SPSS. Based on information appearing in table (7), the computed t-value is 2.997 and the coefficient of significance is 0.003 . Because the computed t-value is higher than the tabulated one that equals $1 . .96$, and because the coefficient of significance is less the predetermined one, which equals 0.05 , the null hypotheses which states that the capital structure of listed firms at ADX doesn't affect the practices of earnings management phenomenon, is rejected. In opposite, the alternative hypothesis which states that capital structure affects earnings management practices is accepted. In other words, the test of the hypotheses finds that the capital structure of listed firms in ADX affects the practices of earnings management phenomenon of these firms.

Table 7. Statistics of the Effect of Debt Ratio on Discretionary Accruals

\begin{tabular}{|l|l|l|l|l|}
\hline Hypothesis & Adjusted $\mathbf{R}^{\mathbf{2}}$ & T-Value & $\begin{array}{l}\text { Significance } \\
\text { Coefficient }\end{array}$ & $\begin{array}{l}\text { Standard } \\
\text { Error }\end{array}$ \\
\hline Ho2 & 0.065 & 2.997 & 0.003 & 0.022 \\
\hline
\end{tabular}

The table shows the regression Statistics of the Effect of Debt Ratio on Discretionary Accruals

Based on the results of regression analysis, the model of the study takes the following form

$$
\mathrm{EM}=-0.39+0.022 \mathrm{Dt}+0.022
$$

\section{Findings and Conclusions}

The primary two objectives of the study is to identify whether listed firms in ADX practice the phenomenon of earnings management, and to examine whether the capital structure of these firms affects the practices of earnings management. Data of a sample consisting of 29 listed firms had been collected covering the period2012-2015, and analyzed. Both of the two 
hypotheses that constructing the study had been tested using the binomial distribution test for practices of earnings management, and the simple linear regression method for the impact of capital structure. The analysis of discretionary accruals revealed that listed firms at ADX have practices of earnings management. Data covering the period 2012-2015 regarding debt ratio for the firms included in the sample had been analyzed with discretionary accruals of the same period, and the finding shows no significant effect of capital structure on earnings management practices. This conclusion means that whether firms use more or low debts in its capital structures, the practices of earnings management will not be affected.

The findings of the study is in agreement with Mozarpour and Nourouzi (2015), An, Li, and Yu, (2013), Zamri, Abdul Rahman, Isa, (2013), and Roodpohti and Chashmi (2011). Therefore, more studies are required to the relationship between the capital structure and earnings management. In addition, more research recommended to the relationship between debt weight in the capital structure of firms, since still the relationship is still questionable.

\section{References}

Abu Ajeelah E. M., \& Hamdan, A. (2009). The Impact of Corporate Governance on Earnings Management: Evidence from Jordan, Working Paper, The Global Financial and Economic Crisis and Corporate Governance, Suteif University, Algeria, October 20-21, 2009, available on Line at: http://iefpedia.com/arab.

Al Momani, M. A. (2016). The Ability of Traditional and Modern Performance Indicators in Interpreting the Phenomenon of Earnings Management: Evidence Manufacturing Firms In Amman Stock Exchange. Asian Journal of Finance \& Accounting, 8(2), 77-99. https://doi.org/10.5296/ajfa.v8i1.8943

An, Z., Li, D., \& Yu, J. (2013). Earnings Management, Capital Structure, and the Role of Institutional Environments, Available: file://C:users/USER/Downloads/ssrn-id2207804.

Benkraiem, R. (2012). Board Independence, Corporate Governance and Earnings Management in France. Available: http://link.springer.com/chapter.

Beatty, A., and Weber, J. (2008). The Effects of Debt Contracting on Voluntary Accounting Method Changes. The Accounting Review, 78(1), 119-142. https://doi.org/10.2308/accr.2003.78.1.119

Cabej, E. (2013). Earnings Management and Firms size: An Empirical Analyze in AlAlbanian Market. European Scientific Journal, 9(16), 135-143.

Chen, X., Cheng, Q., \& Wang, X. (2011). Does Increased Board Independence Reduce Earnings Management? Evidence from Recent Regulatory Reforms. Available: http://www1.american.edu/academic.depts/ksb/finance_realestate/mrobe/Seminar/QCheng.pd f.

Dechow, P. M., \& others (2011). Detecting Earnings Management: A New Approach, Working Paper, Available: http://ssrn.com/abstract=1735168. 
Dechow, P. M., Sloan, R. G., \& Sweeney, A. P. (1995). Detecting Earnings Management. The Accounting Review, 70(2), 193-225.

Gaa, J. (2007). The Ethics of Earnings Management: The Case of Income Smoothing, Working Paper, University of Alberta, available:Jg310507_slides.pdf.

Healy, P. M., \& Wahlen, J. M. (1998). A Review of the Earnings Management Literature and its Implication for Standard Setting, Available: homepages.rpi.edu./home/17/wuq2/public.../healy\%201999.pdf.

Islam, M. A., Ali, R, \& Ahmed, Z. (2010). Is Modified Jones Model Effective in Detecting Earnings Management? Evidence from A Developing Economy. International Journal of Economics and Finance, 3(2), 116-125.

Jelinek, K. (2007). The Effects of Leverage Increases on Earnings Management. Journal of Business Economics Studies, 13(2), 26-46.

Kighir, A., Omar, N., \& Mohamed, N. (2014). Earnings Management Detection Modeling: A Methodological Review. World Journal of Social Sciences, 4(1), 18-32.

Kim, Y., \& Liu, C. (2003). The Effect of Firm Size on Earnings management, Working paper, Available: http://citeseerx.psu.edu.

Kontorizos, G. ((2008). Financial Indications Behind Earnings Management Practices in Europe, Master thesis, Erasmus University of Rotterdam.

Lev, B. (1989). On the Usefulness of Earnings and Earnings Researches: Lessons and Directions from Two Decades of Empirical Research. Journal of Accounting Research, 27, 153-192. https://doi.org/10.2307/2491070

Levitt, A. (1998). The Numbers Game, Unpublished Remarks, Retrieved Aug. 29, 2015 from http://www.SEC.gov/news/speech/spch220.txt.

Liu, J., Harris, K., \& Omar, N. (2013). Board Committees and Earnings Management. Corporate Board: Role and Duties, 9(1), 6-17.

LO, K. (2007). Earnings management and Earnings Quality, Available: SSRN Electronic Journal.

Miloud, T. (2014). Earnings Management and Initia Public Offerings: An Empirical Analysis. The Journal of Applied Business Research, 30(1), 117-134. https://doi.org/10.19030/jabr.v30i1.8288

Patrick, E. A., Paulinus, E. C., \& Nympha, A. An (2015). The Influence of Corporate Governance on Earnings Management Practices: A Study of Some Selected Quoted Companies in Nigeria. American Journal of Economics, 1(5), 482-493. 
Peasnell, K. V., Pope, P. F., \& Young, S. (1999). Detecting Earnings Management Using Cross-Sectional Abnormal Accruals Models. Accounting and Business Research, 30(4), 1-31.

Rani, P., Hussain, F. F., \& Chand, P. V. (2013). Managerial Incentives for Earnings Management among Listed Firms: Evidence from Fiji. Global Journal of Business Research, $7(1), 21-31$.

Rahman, M. M, Moniruzzaman, M., \& Sharif, M. J. (2012). Techniques, Motives, and Controls of Earnings Management. International Journal of Information Technology and Business Management, 11(1), 22-34.

Roodposhti, F. R., \& Chashmi, S. A. N. (2011). The Impact of Corporate Governance Mechanisms on Earnings Management. African Journal of Business Management, 5(1), 4143-4151.

Roychowdhury, S. (2006). Earnings Management through Real Activities Manipulation. Journal of Accounting and Economics, 42, 335-370. https://doi.org/10.1016/j.jacceco.2006.01.002

Schipper, K. (1989). Commentary on Earnings Management. Accounting Horizons, 3(4), 91-102.

Tahir, S. H (2011). Impact of Earnings Management on Capital Structure: A Case Study of Karachi Stock Exchange (KSE). Global Business and Management Research, 3(1), 96-105.

Uwuigbe, U., Ranti, U. O., \& Bernard, O. (2015). Assessment of the Effects of Firm's Characteristics on Earnings Management of Listed Firms in Nigeria. Asian Economic and Financial Review, 5(2), 218-228. https://doi.org/10.18488/journal.aefr/2015.5.2/102.2.218.228

Uwuigbe, U., Peter, D. S.,\& Oyeniyi, A. (2014). The Effect of Corporate Governance Mechanisms on Earnings Management of Listed Firms in Nigeria. Accounting and Management Information Systems, 13(1), 159-174.

Wasimullah, Toor, I. K., \& Abbas, Z (2010). Can High Leverage Control the Opportunistic Behavior of Managers: Case Analysis of Textile Sector of Pakistan. International Research Journal of Finance and Economics, ISSN, 140-2887, 47.

Zhang, Z., \& Liu, X. (2009). The Effect of capital Structure on Earnings Management:Empirical Evidence from China, Working Paper, Information Science and Engineering, 2009 1st International Conference along 26-28 December 2009.

Zamri, N., Abdul Rahman, R., \& Isa, N. (2013). The Impact of Leverage on Earnings

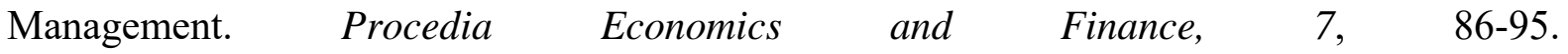
https://doi.org/10.1016/S2212-5671(13)00222-0 